essentially human. Asymmetry of the brain is common. The occipital lube is often undeveloped. Hypertrophy of the brain is not unfrequent. A huge cranium with completely ossified sutures may coexist with a hypertrophied brain. The cranium may be greatly thickened. More or less complete absence of commissures may be met with. The corpus callosum has been absent in 2 per cent., and the soft commissure in 8 per cent., of Dr. Down's post-mortem examinations. Pallor of the grey matter is of very frequent occurrence. Indeed, nothing is more striking than the frequent mention of whiteness of this part. Dr. Down could not but think that this phenomenon afforded indications for treatment and hopeful prognosis - as to the possibility of functional improvement of the brain.

Treatment resolves itself into physical and medical, and moral and intellect ual training. Treatment should be begun betimes. Early training is of importance in preventing the growth of bad habits. Dr. Down avers that he knows nothing of cataclysmal improvements at seven and fourteen years of age. These ages are developmental crises full of danger. The most successful training is effected by placing the child with its peers, and not with its superiors. Intelligent children will not take part in the amusements and games of feeble-minded ones. It is important to rescue the feeble one from a solitary life, to give him companionship with his equals, and to place him in a condition where all the machinery moves for his benefit, where he is surrounded by influences of art and nature calculated to make life joyous, to arouse his observation, and to quicken his power of thought. In the families of the wealthy feeble-minded children do not receive the needful education and the necessary attention. It must always be kept in mind that the basis of all treatment should be medical in the large sense of the word. Success can only be attained by keeping the patient in the highest possible health. This is demonstrated by the increased intellectual torpor that accompanies deterioration of bodily health, and also by the diminished intellectual vigour observed in cold weather. A very liberal dietary is of great importance. It should contain a fair quantity of nitrogenous elements, and be rich also in phosphates and oleaginous constituents. Green vegetables are very essential as a valuable antiscorbutic. Too much farinaceous food should be avoided. Semolina, entire wheat flour, or macaroni are the best. The food must be easy to masticate. The bed-and sitting-rooms should be spacious, well warmed, and ventilated. The skin should be frequently sponged; the exhalation from it in the feebleminded is something sui generis. A gravel soil, with wellmade walks and plenty of out-door exercise and warm clothing, are most necessary. Summer brings with it a remarkable immunity from disease. Gymnastics, massage, and galvanism are employed to improve the condition of the muscles. Volitional movements should take the place of automatic ones. Simple ones are first practised. Finger lessons should precede tongue lessons. Dr. Down always remembers the pinioned Frenchman who entreated that his arms might be freed because he wanted to speak. The physical quality of the brain and other nervous centres must be improved, and this will bring the patient into practical relation with the external world and initiate reasoning. The moral training is of great importance. The patient's will must be brought into subjection to that of another. He has to learn obedience, that right-doing brings pleasure, and wrong-doing deprivation of pleasure. The affective faculties should be so cultivated that loss of the teacher's love should be felt as the greatest punishment, and vice versit. In this way indications of untruthfulness, selfishness, obstinacy, sensuality, theft, and unkindness are checked. Corporal punishment should be strictly forbidden. Nothing is worse than deprivation of food as a punishment for an offence. Moral delinquency may be the result of mental excitement, the outcome of defective nutrition. The intellectual training must be based on a cultivation of the senses. They should be taught the qualities of form and the relation of objects by the sense of touch; the colour, size, shape, and relation by sight; the understanding of the various sounds; the qualities of objects presented to taste or smell. The concrete, not the abstract, should be taught. Dressing and undressing should be taught. Habits of order and neatness, of dexterity in the use of the knife, spoon, or fork, of precision in walking and handling, should be inculcated. Defective speech is best overcome by a wellarranged plan of tongue gymnastics, followed by a cultivation of the purely imitative powers. Monosyllabic sounds having concrete representatives should be first taught. The transactions of buying and selling may be easily arranged for amongst the patients themselves. House and school instruction should be supplemented by gardening and farming operations. The lathe, the fretwork machine, carpenter's bench, and printer's shop are useful appliances and means. For girls kindergarten occupations and the various elegancies of needlework may be the outcome of persevering effort Music and dancing may, for all, alternate with dramatic entertainments, which appeal to eye and ear.

\section{A CASE OF WOUND OF THE COMMON} FEMORAL VEIN; SECONDARY HÆMOR. RHAGE FROM THE COMMON FEMORAL ARTERY ; SEPTICAMIA ; DEATH. ${ }^{1}$

By A. PEARCE GOULD, M.S.,

ASSISTANT-SURGEON TO THE MIDDLESEX HOSPITAL.

THe wound of a vein is, as a rule, less serious and more easily dealt with than a wound of the corresponding artery, and for this among other reasons wounds of veins have received but scant notice at the hands of most surgical writers. Wounds of very large veins, however, are very grave injuries, and there are several interesting questions connected with their treatment which may be considered as still open to discussion. Having recently had to treat a case of wound of the common femoral vein attended with grave complications, I have thought an account of it might. be considered worthy of attention.

On the evening of Oct. 11th, 1886, M. M- - an Italian ice-cream seller, was stooping down in the street, when on rising he came in contact with the knife of a cat's-meat woman who was standing by his side, the knife entering his left groin. Blood flowed very freely, and be went to \& neighbouring chemist, who applied a pad and bandage and sent him to Middlesex Hospital. On his arrival at the hospital the hæmorrhage had ceased, but while the housesurgeon (Mr. Livermore) was preparing to readjust the pad the man vomited, and at once a full stream of venous blood spurted from the wound. A compress was firmly bandaged on and I was sent for.

I found the man pale, cold, and rather faint from loss of blood, and as the hæmorrhage had been so abundant I determined to secure the wounded ressel, An anæsthetic was administered by Mr. Fardon, and a Petit's tourniquet was applied to the thigh below the wound. The wound was a clean cut half an inch longr immediately below and parallel to Poupart's ligament and exactly over the common femoral artery; a probe passed into it slipped downwards and inwards. There was no alteration in the femoral or tibial pulse. I enlarged the wound by a vertical incision about three inches long, and turned out a considerable quantity of clotted blood which was lying beneath the fascia lata; upon this very free venous hæmorrhage ensued, which was with difficulty held in check by digital pressure above the wound. I then passed my finger into the bottom of the wound, and found that it passed quite into the common femoral vein through a wound which severed the whole anterior segment of the vessel. A ligature was passed around the vein above and below the wound and tied. This did not arrest the bleeding, which was then seen to come from the internal saphena vein, which entered the femoral just opposite the wound; a ligature was passed around this vein and tied. But blood still welled up from the wounded vessel, and further search showed that another vein entered the femoral trunk just opposite the wound in the segment between the two ligatures. This vein was tied, and then all hæmorrhage was found to be arrested. The ligatures were of carbolised silk. The femoral vein was divided between the two ligatures. The man lost a good deal of blood during the operation, which was attended with considerable difficulty owing to the impossibility of completely arresting the hæmorrhage by pressure above and below. The femoral artery was clearly seen during the operation, but was apparently uniniured. The wound was very thoroughly irrigated with solution of

A paper read at a recent meeting of the Medical Society of London. 


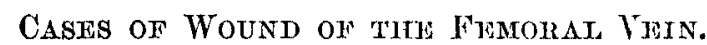

\begin{tabular}{|c|c|c|c|c|}
\hline Surgeon. & Reference. & Injury. & Treatment. & Result. \\
\hline Langenbeck & Langenbeck's Archiv., i., 1 & $\begin{array}{l}\text { Wound of femoral vein during removal of } \\
\text { sarcoma of groin }\end{array}$ & Ligature of femoral artery & Recovery \\
\hline Oettingen & $\begin{array}{l}\text { "International Encyclop. } \\
\text { of Surgery," vol. iii. } \\
\text { (Dr. Lidell's article) }\end{array}$ & $\begin{array}{c}\text { Wound of femoral vein during removal of } \\
\text { tumour of groin }\end{array}$ & $\begin{array}{l}\text { Double ligature of vein; } \\
\text { ligature of femoral artery }\end{array}$ & Recovery \\
\hline McClellan & Ditto & $\begin{array}{l}\text { Wound of the internal saphena vein at the } \\
\text { entrance to the femoral vein, during } \\
\text { excision of tumour in the groin }\end{array}$ & $\begin{array}{l}\text { Lateral ligature of the } \\
\text { femoral vein }\end{array}$ & Recovery \\
\hline Roux & $\begin{array}{l}\text { Gazette des Höpitaux, } 1853 \\
\text { (quoted by Nicatse) }\end{array}$ & $\begin{array}{l}\text { Wound of femoral vein above saphena during } \\
\text { removal of tumour in the groin }\end{array}$ & $\begin{array}{l}\text { Double ligature of the } \\
\text { femoral vein }\end{array}$ & Recovery \\
\hline McClellan & Dr.Lidell, op. cit. & $\begin{array}{l}\text { Wound of femoral vein and exposure of the } \\
\text { femoral artery by a blunt hook }\end{array}$ & $\begin{array}{l}\text { Ligature of femoral artery; } \\
\text { compression of wounded } \\
\text { vein }\end{array}$ & $\begin{array}{l}\text { Gangrene } \\
\text { of leg; } \\
\text { amputation; } \\
\text { recovery }\end{array}$ \\
\hline ollier & Quoted by Nicaise & Wound of femoral vein in groin & $\begin{array}{l}\text { Suture of skin wound } \\
\text { light compression }\end{array}$ & Recovery \\
\hline Delore & Ditto & Wound of femoral vein & $\begin{array}{l}\text { Compression above the } \\
\text { wound }\end{array}$ & $\begin{array}{l}\text { Death from } \\
\text { haemorrhage }\end{array}$ \\
\hline Ronx & Ditto & $\begin{array}{l}\text { Compound fracture of the middle third of the } \\
\text { femur; wound of the femoral vein }\end{array}$ & $\begin{array}{l}\text { Wound enlarged; hæmor- } \\
\text { rhage arrested by plugging }\end{array}$ & Recovery \\
\hline Larrey & $\begin{array}{l}\text { Quoted by Nicaise } \\
\text { (Clin. Chir., t. iii.) }\end{array}$ & $\begin{array}{l}\text { Sabre-wound of groin dividing saphena } \\
\text { vein at the entrance to the femoral rein }\end{array}$ & $\begin{array}{c}\text { Ligature of femoral and } \\
\text { saphena veins }\end{array}$ & Recovery \\
\hline Garretson & $\begin{array}{l}\text { "Medical and Surgical } \\
\text { History of the War of the } \\
\text { Rebellion," second Surgical } \\
\text { volume }\end{array}$ & Wound of femoral rein & $\begin{array}{l}\text { Double ligature of femoral } \\
\text { vein ; single ligature of } \\
\text { femoral artery }\end{array}$ & Death \\
\hline Leale & Ditto & $\begin{array}{c}\text { Gunshot-wound of femoral vein and } \\
\text { prostate }\end{array}$ & Compresses & $\begin{array}{l}\text { Death on } \\
\text { the 13th day }\end{array}$ \\
\hline 'Pogue & Ditto & Gunshot-wound of femoral vein & - & $\begin{array}{l}\text { Death on } \\
\text { the 17th day }\end{array}$ \\
\hline- & Ditto & Gunshot-wound of femoral rein & - & $\begin{array}{l}\text { Death on } \\
\text { the 18th day }\end{array}$ \\
\hline- & Ditto & Wound of femoral vein & - & Death \\
\hline- & Dr. Lidell, op. cit. & Wound of femoral vein and crural nerve & Compresses and styptics & Death \\
\hline Agnew & Quoted by Lidell & $\begin{array}{c}\text { Wound of femoral vein during ligature of } \\
\text { artery for aneurysm }\end{array}$ & Ligature of artery & Recovery \\
\hline Travers & $\begin{array}{l}\text { " Surgical Fissays," by } \\
\text { Cooper and Travers }\end{array}$ & $\begin{array}{c}\text { Wound of femoral vein during ligature of } \\
\text { artery for aneurysm }\end{array}$ & - & 一 \\
\hline Gensoul & Quoted by Nicaise & $\begin{array}{l}\text { Gunshot-wound of middle of thigh, } \\
\text { fracturing femur; secondary hæmorrhage } \\
\text { from femoral vein }\end{array}$ & $\begin{array}{l}\text { Ligature of common femoral } \\
\text { artery }\end{array}$ & $\begin{array}{l}\text { Death on the } \\
7 \text { th day; no } \\
\text { gangrene }\end{array}$ \\
\hline Desprès & $\begin{array}{c}\text { Quoted by Nicaise } \\
\text { (Soc. de Chir., Oct. 18th, } \\
\text { 1871) }\end{array}$ & $\begin{array}{l}\text { Wound of upper part of thigh ; secondary } \\
\text { bæmorrhage }\end{array}$ & Ligature of femoral vein & Recovery \\
\hline Nelson & $\begin{array}{l}\text { "Medical and Surgical } \\
\text { History of the War of the } \\
\text { Rebellion," Part 3rd }\end{array}$ & $\begin{array}{l}\text { Gunshot-wound of groin; sloughing; } \\
\text { pyamia; secondary hemorrhage from a } \\
\text { wound of femoral rein by a needle }\end{array}$ & Ligature of femoral artery & Deatì \\
\hline- & $\begin{array}{c}\text { "International Encyclop. } \\
\text { of Surgery" (Dr. Lidell), } \\
\text { vol. iii. }\end{array}$ & Wound of femoral artery and vein & - & $\begin{array}{l}\text { Death in a few } \\
\text { moments }\end{array}$ \\
\hline$\because$ & Ditto & Wound of femoral artery and vein & - & $\begin{array}{l}\text { Death in a few } \\
\text { moments }\end{array}$ \\
\hline Rose & Ditto & $\begin{array}{c}\text { Punctured wound of femoral artery and } \\
\text { vein }\end{array}$ & $\begin{array}{l}\text { Double ligature of femoral } \\
\text { artery and vein }\end{array}$ & Recovery \\
\hline- & Dr. Lidell's article, op. cit. & $\begin{array}{c}\text { Gunshot-wound of femoral artery and } \\
\text { vein }\end{array}$ & $\begin{array}{l}\text { Ligature of femoral artery } \\
\text { and vein }\end{array}$ & $\begin{array}{l}\text { Gangreue } \\
\text { death }\end{array}$ \\
\hline Dougherty & $\begin{array}{l}\text { "Medical and Surgical } \\
\text { History of the War of the } \\
\text { Rebellion," second Surgical } \\
\text { rolume }\end{array}$ & $\begin{array}{c}\text { Gunshot-wound of femoral artery and } \\
\text { vein }\end{array}$ & $\begin{array}{l}\text { Double ligature of femoral } \\
\text { artery aud vein ; ampu- } \\
\text { tation }\end{array}$ & Death \\
\hline- & Ditto & Wound of femoral artery and vein & Amputation & $\underset{\text { death }}{\text { Pyonia }}$ \\
\hline- & Ditto & Wound of femoral artery and vein & Amputation on nivth day & Death \\
\hline Thomson & Ditto & Wound of thigh ; secondary hemorrhage & $\begin{array}{l}\text { Ligature of femoral artery } \\
\text { and vein }\end{array}$ & $\begin{array}{l}\text { Gangrene ; } \\
\text { deatl }\end{array}$ \\
\hline Thomson & Ditto & Wound of femoral artery and vein & $\begin{array}{l}\text { Double ligature of femoral } \\
\text { artery and vein }\end{array}$ & Death \\
\hline Gayet & Quoted by Nicaise & Wound of femoral vein and profunda artery & Lig. of external iliac ariery & Death \\
\hline
\end{tabular}


bichloride of mercury ( 1 in 2000 ), and was closed with catgut sutures, a drainage-tube being inserted at the lower angle, and dressed with sal alembroth wool. A flannel bandage was rolled around the limbs, and the man was returned to bed with the knee slightly flexed. A quarter of a grain of morphia was given hypodermically.

Oct. 12th. - Next morning be appeared comfortable; pulse 96 ; temperature $984^{\circ}$; sweatiug treely. The leg and foot were nearly as warm as the other side, and there was no odema. The temperature rose in the evening to $101 \cdot 2^{\circ}$; and the urine was drawn off by catheter, as none had been passed.

13th.-Temperature $1036^{\circ}$; pulse 100 ; profuse sweating patient restless at times. One grain of opium was ordered every six hours. The wound was dressed; there was no redness of the edges, swelling, or bagging. The drainagetube was removed. At 9 P.M. the temperature was $104^{\circ}$, and, as the bowels had not acted, an ounce and a half of compound senna mixture was given.

14th.-Temperature $101^{\circ}$. Bowels acted five times during the night, and this diarrhœa continued through the day, in spite of the opium which was taken. There was slight codema of the left foot and lower part of the leg.

15th.-Temperature $101^{\circ}$; pulse 108. Diarrhoea has ceased. The wound was dressed, and a considerable quantity of turbid serum oozed from it. The highest two stitches were removed, the edges separated, and the cavity was well washed out with corrosive sublimate solution ( 1 in 2000).

16th.-Temperature $100^{\circ}$; pulse 96 ; no sweating. On removing the dressing the edges were found sloughy, so the remaining stitches were removed, the edges separated, and the part well irrigated with corrosive sublimate.

17th.-Delirium set in; at 12 noon he had a fit, being seized with tremors and cough, followed by dyspnoa, the patient with wide-open mouth gasping for breath for four or five minutes. The wound was dressed and well irrigated. One-sixth of a grain of morphia was injected, but he slept only a very short time after it, and at night a mixture containing half a drachm of bromide of potassium, one scruple of chloral hydrate, and fifteen minims of tincture of hyoscyamus was ordered to be given every hour until sleep was obtained. The delirium was closely like delirium tremens. Four doses of this mixture produced no effect, and the man had a very restless night. At 4 A.M. one-sixth of a grain of morphia was again injected under the skin.

18th.-The patient has had two hours' sleep, and is much more sensible. The wound looks healthier. During the day he had three injections of one-sixth of a grain of morphia.

19th.-He had had a fairly good night and was better; the edges of the wound were granulating. He was quiet all through the day, and took nourishment well.

20 th. - The improvement continued; in the evening he passed urine voluntarily for the first time.

At 12.30 A.M. on the morning of Oct. 21st, after a violent fit of coughing, profuse hæmorrhage came on, and a good deal of blood was lost before aid arrived. The artery was controlled above Poupart's ligament, and Mr. Livermore seized the bleeding point with pressure-forceps. I was sent for, and had the patient placed under the influence of chloroform. I found that the bleeding came from the common femoral artery; without difficulty I placed a silk ligature upon the vessel close below Poupart's ligament. The vessel was softened, and obviously unfit for a ligature as far down as the origin of the profunda, so a ligature was placed around both the superficial and the deep femoral arteries; this entirely arrested the hæmorrhage. The wound was again irrigated with the mercury solution, and dressed as before with alembroth wool. The limb was wrapped in a thick layer of cotton-wool, and hot bottles were placed in the bed.

The patient never recovered from the effects of the loss of blood, and he died in the evening of Oct.22nd. During the last five days of his life the foot and leg became more cedematous, and especially was this so after the second operation. The foot and leg did not regain their warmth after the ligature of the artery.

The necropsy was made nineteen hours after death by $\mathrm{Mr}$. Roger Williams. Rigor mortis was present, and the body was jaundiced in appearance. The two ends of the femoral artery were separated by about two inches, each secured by a ligature; in the upper end was found a rather firm reddish clot, which extended up to and obliterated the origin of the deep epigastric artery ; the distal end was filled by a much smaller and softer clot, about three inches long. The tied end of the profunda femoris artery was found between the ends of the femoral artery. The upper end of the femoral vein was found with its ligature lying loose by it; there was no ligature over or near the distal end. A ligature was found around the internal saphena vein, and another around the external circumflex vein. The profunda vein entered the lower end of the femoral vein. There was a broken-down clot filling the external iliac vein from the entrance of the circumflex iliac vein and extending almost up to the vena cava. The leitt lower limb was deeply congested, and swollen from œedema and gas generated by decomposition. Liver and kidneys fatty. The spleen weighed $14 \frac{1}{4} \mathrm{oz}$, and was deeply congested. The endocardium on the right side of the heart was stained red.

Remarks.-I would submit the following interpretation of this case:-The wound of the vein was made with an infected knife. Antiseptic irrigation failed to remove all the infective material, which, remaining behind, set up inflammation in the wound and led to the breaking down of the thrombus in the vein. The femoral artery may have been bruised at the time of the original injury, although it showed no signs of it at the time, and the treatment pursued -plugging the wound, \&c.-may have injured it, and so its walls quickly yielded to the septic processes in the wound and secondary hæmorrhage ensued, necessitating ligature of arteries. Meanwhile the septic thrombus had been spreading up the iliac vein until all the direct channels for the venous blood returning from the lower limb were blocked, and with this moist gangrene occurred, its full development being prevented by the death of the patient from general blood-poisoning, accelerated by loss of blood.

The consideration of this case naturally divides itself into two heads - the occurrence of the septicæmia and the proper treatment of a wound of the common femoral vein.

1. The septicamia.-Of the fact of septic infection of the wound, with the formation of a spreading, softening thrombus in the iliac vein, there can be no doubt; but exactly to determine how this infection was occasioned is a more difficult matter. My own impression is that the cat's-meat knife was the carrier of the infection, and that my antiseptic irrigation, although carried out with a special view to this contingency, failed to remove all the infective. material. All the usual precautions in wound treatment were adopted: the ligatures were of silk, which had been boiled in carbolic acid solution ( 5 per cent.), and kept in the. same liquid. To the occurrence of this septic infection of the wound the fatal result is due, for it prevented the healing of the wound by first intention, was an important factor in the production of the secondary hæmorrhage, led to the complete closure of the channels for the venous return from the limb, and induced the constitutional change which was manifested by fever, sweating, diarrhœea, delirium, and jaundice.

2. The treatment of the wounded vein. - From the "Medical and Surgical History of the War of the Rebellion," Dr. Lidell's article in Ashhurst's "International Encyclopædia of Surgery," and Nicaise's "Thesis," I have collected the following cases of wounds of the femoral vein. The cases in the accompanying table (page 259) illustrate: several varieties of wound of the femoral vein: $(a)$ wound of the vein during the removal of tumours, four cases. all ending in recovery; $(b)$ accidental wound of the vein by bullet, sabre, hook, or fragment of bone, eleven cases-only three of these patients escaped with their life; (c) wound of the femoral vein during ligature of the artery for aneurysm, two cases; $(d)$ secondary hæmorrhage from the femoral vein, three cases, one of which recovered; $(e)$ simultaneous wound of the femoral vein and the femoral or profunda artery, ten cases, with only one recovery. As in so many other statistical inquiries the cases have varied so much in their nature, and in $\operatorname{som} \theta$ instances the reports are so scanty, that this table cannot be relied upon as a safe and sufficient guide to the treatment of a wounded femoral vein. But at the same time it shows certain facts, the most striking of which is the variety of treatment that has been adopted, and the success that has attended almost every means used.

Ligature of the wounded vein. - The table shows four cases, in one of which the ligature was applied laterally; all these patients recovered, and no mention is made of subsequent œdema or congestion, still less of gangrene. On the other hand, Verneuil is quoted by Nicaise as having had three cases of lateral ligature of the femoral vein, all fatal. During the removal of cancerous glands from the groin on one occasion I had to tie the saphena vein at its juncture with the femoral vein. The man recovered, without any symptom referable to venous obstruction. In 
M'Clellan's case of lateral ligature of the vein, he speaks of the wound as a Jarge one. The relative value of the lateral and circular ligature is the same in the femoral vein as in other situations, and although many cases of successful lateral ligature of large veins are recorded, the fatalities are too numerous to warrant its repetition, except in the case of punctures and small wounds.

Ligature of the femoral artery.-. The table shows in all six cases, three ending in recovery, and three in the death of the patient. The best known case is that of Langenbeck, who failed to secure the vein, and then, on ligating the artery, found the venouls hæmorrhage stop. In one of the cases the ligature was placed upon the external iliac artery.

Ligature of the femoral artery and vein.-This was done in three cases for wound of the femoral vein only (including one case of wound of the ending of the saphena vein), with two recoveries; and in four cases for simultaneous wound of the two vessels, with one recovery and three deaths. The ligature of an artery for wound of the corresponding wein was first done by Gensoul in 1831; but Langenbeck's name is specially associated with this form of treatment, which has been advocated also by Tillmanns and others. Langenbeck urged that the danger of ligating the main rein of a limb was the occurrence of gangrene from venous obstruction, and that by tying the main artery the supply of blood to the limb was so reduced that this danger was obviated. There are two sufficient answers to this argument: in the first place, it has been shown that ligature of the main vein of a limb does not produce gangrene so long as the various accessory channels of venous return are patent; in the second place, ligature of an artery lessens very materially for a time the vis a tergo of the blood in the capillaries and veins, and therefore reduces the force which is opposed to the venous obstruction. I have three times ligatured the axillary vein while removing malignant gnowths from the axilla, and have not observed any serious effects upon the circulation, and many cases might be quoted to show that Langenbeck over-estimated the injurious effects of ligature of the main vein of a limb.

The treatment of a wound of such a large vein by compression is not to be recommended, especially in view of the fect that the hæmorrhage, when apparently stayed, is liable to burst out during any expiratory effort, as was the case in my patient. Ollier's case, in which the only treatment adopted was suture of the skin wound and light compression, is a very striking one, and may serve as a good example in like instances.

The best treatment, therefore, appears to be the ligature of the wounded vein, and should I meet with another similar case this is the practice I am prepared to follow. When the secondary hæmorrhage occurred, the question of amputation suggested itself, but such a course would aave been quite unjustifiable in view of the success which has sometimes attended ligature of the femoral artery and vein. In my case it would have been doubly wrong, for it would have inflicted a most serious injury upon a patient already doomed to death from the septic thrombus in his iliac veins. In a table of cases of hremorrhage from veins in the "Surgical History of the American War," fifteen vases of wound of the femoral vein are mentioned, of which only two recovered.

\section{\$OME CONSIDERATIONS IN REGARD TO THE CAUSATION OF SEX.}

\section{By 1. J. WALL, M.D. LoND.,} H. M. INDIAN ARMYY.

So many theories have been put forward as to the ceusation of sex that it would require much time even to vtate them. The object, however, in view at present is to propound no theory whatever, but simply to examine facts that may have a bearing on the subject, and, if possible, to bring out any relation that may be found to exist between the occurrence of sex and any well-ascertained circumstances in regard to the parents, and to draw therefrom any conclusions that may seem just.

In the lower animals there are so many different arrangements of the procreative process that it is not easy to determine what is the exact relation they bear to sex as seen in the higher members i $f$ the animal series. Of course, the essential point in all reproduction is the same-namely, the sepuration of a portion of the tissue of an organism, and its development after more or less change - a change sometimes so great as to surpass the creations of a fairy taleinto an organism like that from which it took its origin ; and though in by far the greater number of animals the procers has become modified, so that portions of tissue of two organisms unite before development proceeds, yet that it took its origin in the simpler method is evident trom the fact that even so high up in the animal scale as birds the first step in the development of the ovum-cleavage-may occur without any interference of the nule element whatever, though the process continues no further: a survival of great importance as evidence of an earlier and simpler method of reproduction. But, judging from the facts that intermediate between the simplest forms of reproduction and the complex ones, in which two individuals are required, there is a large class in which both sexual elements are placed in one individual, though not necessarily for selfimpregnation, and also that even in the highest animals there is an occasional natural effort to revert more or less completely to this arrangement, it would seem that sex is mertly an abortion of one class of sexual organ in each individual, and we must therefore look upon the sexual form which accompanies this as purely secondary. And widely different in appearance as the sexes in the higher animals often are, yet but remove the sexual organs and you have in each case a being with characteristics between the two. Moreover, if there is any imperfection in the development of the sexual organs, there is generally an approach in outward characteristics to the appearance of the other sex, showing that it requires the presence in perfection of one class of organ to exclude entirely the approximation to the opposite sex.

But the mode in which this suppression of one class of sexual organ has been brought about is exceedingly obscure, though a very cursory glance at the animal world would suggest that it is not al ways produced in the same way. In the class Insecta, for instance, we have in the well-known case of the honey-bee perfect females and sterile females produced from eggs impregnated by the male, but the larvæ of which are fed in different ways; whereas males are produced from eggs that have never received any of the male element at all - a position proved by the fact that if the communication with the spermatheca in the queen be interrupted, the ova then produced only bring forth males, and also that when the common bee is crossed with the Ligurian, only the queens and workers have any trace of the cross-breeding, the males being purely of the race of the queen from whom they proceed. In ants also it occasionally happens that the workers, who of course take no part in the nuptial flight, bring forth eggs, and as far as observation goes-certainly in Lasius niger and Formica fusca - these eggs invariably produce males. Now, whatever views may be beld as to the cause of sex in man-and many of them are sufficiently eccentric,-no one has ventured to suggest that it is due to the absence or presence of impregnation by the male element. But even in the same group of animals sex is not always arrived at in the same way, for in this very class Insecta-in Chermes abietis for example-no male individuals have ever been detected, and perfect females lay eggs from which only females are produced. In aphides, again, after several generations of sexless forms, perfect males and perfect females are produced for normal sexual reproduction. In looking, therefore, for the cause of sex, we should be even more careful than usual in not generalising too hastily, and any evidence obtained should be applied in reasoning strictly to the group from which it comes till other observations show that it may be safely extended.

As in man differentiation of sex occurs by no means late in foetal life, attention is naturally directed to the condition of the parente, and though we cannot with any prospect of success investigate all the circumstances relating to them, yet there is one fact often ascertainable with precision, and that is the age, which is necessarily correlated with some of the most important conditions of life. It will be, then, the present object to examine all the evidence accessible on this subject, and to see what light is thrown on the occurrence of sex; but it may he well to state at the outset that age of itself cannot be the cause, for both sexes appear to be produced at nearly all possible ages of the parents.

In regard to man, the examination of this question has not attracted the attention it deserves. Sadler, in his "Law of Population" (vol. ii., page 343), gives a table by which 